\title{
AN EMBODIED READING OF EPIPHANIES IN AELIUS ARISTIDES' SACRED TALES
}

\author{
Aldo Tagliabue
}

This article focuses on the Sacred Tales (henceforth ST), Aelius Aristides' first-person account of his terrible diseases and subsequent healing brought about by Asclepius, and sheds new light on this text with the help of the notion of embodiment. In recent decades the $S T$ has received a great deal of attention: ${ }^{1}$ scholars have offered two main readings of this work, oscillating between the poles of religion and rhetoric. Some have read the $S T$ as an aretalogy ${ }^{2}$ while others have emphasised the rhetorical aims of this text and its connection with Second Sophistic literature. ${ }^{3}$

My article focuses on Aristides' epiphanic dreams of Asclepius. Previous studies have considered these passages to be part of the traditional Greek epiphanic discourse, one in which, as argued by Verity Platt, 'the visual sense tends to predominate'. ${ }^{4}$ This focus on sight in the epiphanic tradition matches the importance of seeing in the Greek religious practice: in ancient Greece sacred sites were visited in order to see the god. ${ }^{5}$ My study, however, argues that these passages, by focusing on the narrator's interactive and multisensorial perception of Asclepius, are especially vivid because they present Aristides' perception of the god as embodied and enactive rather than purely visual (I explain these terms below). In the second part of this article, I turn my attention to the ancient readers of the $S T$ : although the linguistic mediation prevents any literary account of epiphany from conveying a full experience of the divine, with the help of narratorial comments Aristides' dreams of Asclepius bring readers close to gaining it. Overall, this article confirms from a new angle the relevance of religion and rhetoric to the understanding of the $S T$, as well as suggesting that the body might play a more important role than usually thought in the ancient response to epiphanies.

1. For recent surveys of bibliography, see Petsalis-Diomidis (2010), 122-26, and Korenjak (2005).

2. See Petsalis-Diomidis (2006), 195, arguing that this text is 'a praise of the god through the personal testimony of the author'. Boulanger, Dodds, Festugière and Perkins can be also numbered in this group; see Downie (2013), 23-35, for a survey of their ideas with bibliographical references.

3. This rhetorical reading of this text was first advanced by Baumgart in 1874 and has recently been proposed by Downie (2013), 34, who presents her own view of the $S T$ as one that 'takes seriously Aristides' rhetorical and literary aims'. On this line, see also Whitmarsh (2004a), 446, who focuses on Aristides' ambiguous reuse of the Odyssey. On the connection between the ST and the Second Sophistic, see Downie (2013), esp. 57-85.

4. Platt (2011), 11.

5. On the importance of $\theta \varepsilon \omega p i \alpha$, 'spectating', in ancient Greek religious practice, see Rutherford (2013). 
Before starting my analysis, two methodological notes are required. First, I clarify my use of the terms 'embodied' and 'enactive perception', which I draw from cognitive studies. ${ }^{6}$ This field is currently dominated by the so-called 'second generation' wave, which argues that human perception is not 'based on abstract, propositional representations', ${ }^{7}$ but shaped by the interaction of body and mind, with the inclusion of different senses and emotions. ${ }^{8}$ Within this new model, which stresses the role of the body in human cognition and can be broadly defined as 'embodied', some scholars identify a subcategory, the 'enactive perception', according to which perceiving is a way of acting as the world makes itself available to the perceiver through his physical movement and interaction with a given object in a precise environment. In other words, the perception of any object is made possible if one gets close to and moves around it. ${ }^{9}$ Within this embodied model, vision is included but is not given a key role, since, as I have argued above, all human senses contribute to an embodied kind of cognition. Throughout my analysis, I draw attention to Aristides' embodied perception of Asclepius by identifying in the text features of 'cognitive style', ${ }^{10}$ one describing perceptions, emotions and multisensorial reactions, ${ }^{11}$ while the more specific enactive perception is expressed by 'kinesic style', ${ }^{12}$ namely 'references to movement, gesture, action'. ${ }^{13}$ By contrast, by 'purely visual' I refer to the traditional scholarly approach to epiphany, which, as I have discussed above, identifies sight as the key sense in perceiving the god.

Secondly, whenever I mention the readers of the $S T$, I refer to an attempted reconstruction of the ancient recipients of this text as people acquainted with Asclepius' cult and willing to take the narrator's information about the god as truth. The former element is suggested by the scarcity of details about Asclepius'

6. My article fits into the recent trend of using cognitive studies to analyse literature. See Herman (2012) and Kukkonen and Caracciolo (2014) concerning modern literature; Butler and Purves (2013) concerning ancient Greek and Latin literature; Grethlein and Huitink (forthcoming) for an enactive study of Homer's Iliad; Harkins (2012a) and (2012b) for studies of Jewish and early Christian texts through the lenses of embodiment.

7. Kukkonen and Caracciolo (2014), 261.

8. See Kukkonen and Caracciolo (2014), 261: 'Second-generation refers to a specific strand in contemporary cognitive science, one foregrounding the embodiment of mental processes and their extension into the world through material artifacts and socio-cultural practices.' A complete bibliography of research on embodiment is beyond the scope of this article: see Kukkonen and Caracciolo (2014) for the most recent. Earlier fundamental books are Damasio (1999), Noë (2004) and Gallagher (2005).

9. In this definition of enactive perception I am rephrasing Noë (2004), 1.

10. See Troscianko (2014), 29, for a similar but not identical use of 'cognitive style'.

11. See Harvey (2006), 4, for the connection between multisensorial language and embodiment. Within the study of the $S T$ scholars have argued that Aristides' presentation of his body in the text may help us to understand 'corporeal codes in imperial-age ethics, medicine, rhetoric, and physiognomy' (Holmes [2008], 8), and, moreover, Holmes (2008), 85, Platt (2011), 263, and Downie (2013), 183, have adopted the notion of Aristides' 'embodied experience' to express the general attention that his text places on his body. However, no one has yet attempted to use the notion of embodiment as a heuristic tool to offer an innovative interpretation of specific passages of the $S T$, as this article seeks to do.

12. Bolens (2012), 21.

13. Bolens (2012), 18. 
religion provided by Aristides (who seems to presuppose the readers' familiarity with it), ${ }^{14}$ while the latter is related to the $S T$ 's construction as 'astounding' by exploitation of the language of $\theta \alpha u ́ \mu \alpha \tau \alpha$, which was likely to generate wonder and belief as the standard response to this text. ${ }^{15}$ I do not exclude the possibility that some people could take a different attitude and use the same $\theta \alpha v \dot{\mu} \alpha \tau \alpha$ to express their own 'sceptical disbelief in the face of the incredible' 16 and to offer 'an ironical reading' ${ }^{\prime}$ of the $S T$, but in this article I do not focus on this alternative response.

\section{Aristides' Embodied and Enactive Experience of Asclepius}

The $S T$ is filled with Aristides' account of the dreams through which Asclepius has saved him. Throughout the text, the divine intervention is often only implicitly addressed, but a few dreams stand out as exceptions as they overtly describe the epiphany of a deity-mostly, but not exclusively, Asclepius. ${ }^{18}$

\subsection{Aristides' Epiphanic Dreams}

Scholars of the $S T$ have already commented upon these passages, which Downie defines as 'explicitly epiphanic in the traditional mode' ${ }^{19}$ and Aristides

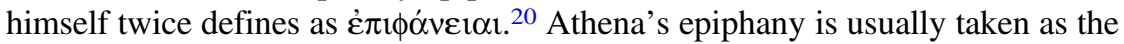
most exemplary one:

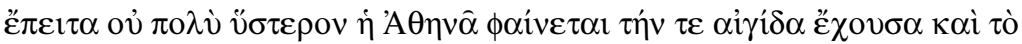

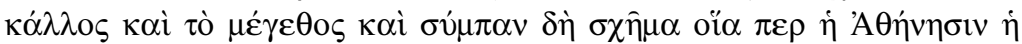

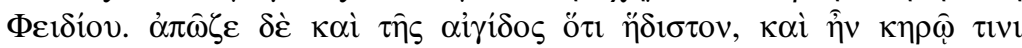

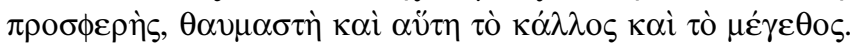

Then not much later, Athena appeared with her aegis and the beauty and magnitude and the whole form of the Athena of Phidias in Athens. There

14. See Petsalis-Diomidis (2010), 130: 'Aristides certainly assumes his reader's familiarity with the basic Asklepian rituals of incubation, and with the occurrence of divine manifestations and interventions.' Cf. Israelowich (2012), 29: 'It appears that the ancient readers of the Sacred Tales all believed they contained credible biographical information regarding Aristides.'

15. See Whitmarsh (2004a), 445, for this reading.

16. I draw this phrase from Whitmarsh's discussion of the language of $\theta \alpha v \dot{\mu} \alpha \tau \alpha$ in Philostratus' Life of Apollonius at Whitmarsh (2004b), 433.

17. Whitmarsh (2004a), 446.

18. See $S T 2.18,2.40$ and 4.50-51 for epiphanies of Asclepius; $2.40-42$ for one of Athena; 3.46-47 for one of Serapis; 4.40 for one of Hermes.

19. Downie (2013), 108.

20. See ST 2.18 and 2.45 . 
was also a scent from the aegis as sweet as could be, and it was like wax, and it too was marvellous in beauty and magnitude. ${ }^{21}$

Platt defines this epiphany as an 'agalmatophany', namely the lively appearance of gods through their images, ${ }^{22}$ and identifies in this passage the phrase $\tau$ ò

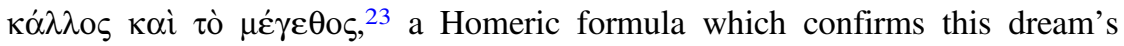
belonging to the traditional Greek epiphanic discourse. At the end of her analysis, Platt gives the following comprehensive assessment of Aristides' epiphanies: ${ }^{24}$

Each deity's manifestation in image form facilitates the verbal transmission of Aristides' epiphanic experience to the reader, so that the unmediated enargeia of his vision can be transformed into the literary enargeia of the Sacred Tales by means of a familiar ekphrastic shorthand.

Here Platt establishes a combination of three elements: vision, which she takes as the key element of the epiphanic experience proper of Aristides and the writers of his time ${ }^{25}$ literary enargeia, which, unlike the 'unmediated enargeia' consisting of the 'experience of a god's full unmediated presence', 26 is 'the quality of creating a vivid, visual image through words' $;{ }^{27}$ and ekphrasis, which according to

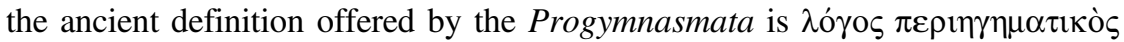

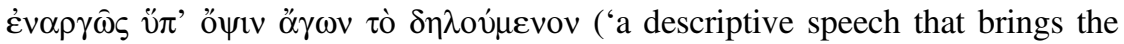
subject matter vividly before the eyes'), ${ }^{28}$ an effect which is usually produced through the reproduction of many details of the given subject. ${ }^{29}$ With these words, then, Platt relates Aristides' dreams to the traditional ancient discourse about epiphanies, which is characterised by a close link between vision and enargeia,${ }^{30}$ and on this basis compares epiphanies with ekphraseis, as throughout ancient literature the latter as well as the former stand out for their visuality and vividness. ${ }^{31}$

21. For the text of Aelius' Sacred Tales, see Dindorf (1964). For the translations, I use Behr (1981) with slight orthographic modifications, apart from a few exceptions noted with the expression 'my tr.'.

22. On the equivalence of 'god' and 'image' in ancient ritual contexts, see Gordon (1979) and Squire (2009), 116. The term 'agalmatophany' comes from Platt (2011), 262.

23. See Platt (2011), 262, who stresses the use of this formula in representations of the divine.

24. Platt (2011), 265.

25. See Platt (2011), 215-92.

26. Platt (2011), 57.

27. Morales (2004), 90.

28. Theon Prog. 118.7-8.

29. On the role of accuracy in writing as an important element of ekphrastic discourse, see Webb (2009), $74 \mathrm{f}$.

30. On the key role of vision and enargeia in epiphany, see again Platt (2011), 11: 'The visual sense tends to predominate in Greek epiphanic discourse, as the ocular profusion of Philostratus' ekphrasis strikingly demonstrates.'

31. Literature on the importance of vision and enargeia in ancient ekphraseis is very extensive; for a rich bibliography, see Morales (2004), 8 n.39 and, with special concern to Imperial literature, Goldhill (2001) and Webb (2009). More broadly, on the close connection in ancient Greek culture between epiphanies and ekphraseis, see Platt (2011), 7: 'Within Greek culture, epiphany (by which I mean the 
The relevance of these two features in ancient epiphanies can be seen in the following extract from Aphrodite's epiphany to Anchises in the Homeric Hymn dedicated to this goddess:

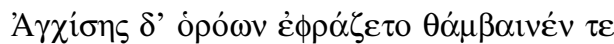

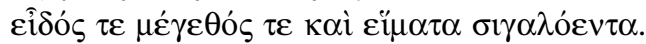

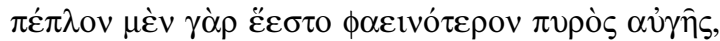

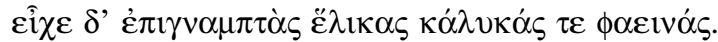

(Hymn. Aphr. 84-87)

Anchises gazed and took stock of her, wondering at her appearance, her stature, and her shining garments; for she wore a dress brighter than firelight, and she had twisted bracelets and shining ear buds.

(tr. West)

As shown by the initial focus on Anchises' eye and the details about the goddess's physical beauty, this passage conveys a vivid and purely visual perception of Aphrodite. ${ }^{32}$

My analysis of the $S T$ addresses some of Aristides' epiphanies-those dedicated to Asclepius - and introduces a different interpretation, as I read these passages as conveying Aristides' enactive rather than purely visual perception of the god-one that takes place through the interaction between Aristides' cognitive faculty and Asclepius in precisely described spaces. ${ }^{33}$ This reading can be offered by highlighting a key feature of these passages that has passed so far unnoticed, their kinesic style. Aristides' enactive dreams focus on spatiality, actions and gestures, and, conversely, do not focus on the visual perception of the god.

The first epiphanic encounter between Aristides and Asclepius takes place in Book 2:

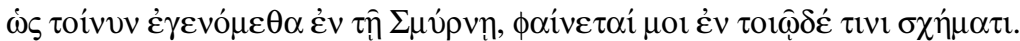

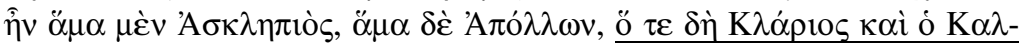

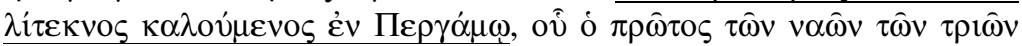

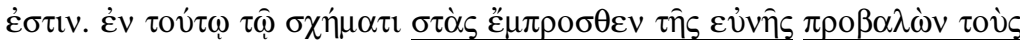

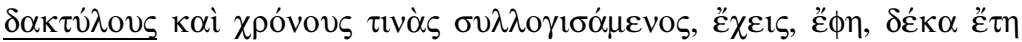

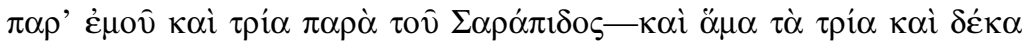

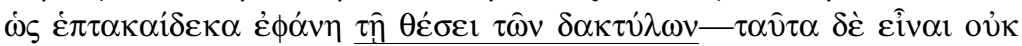

manifestation of deities to mortals) inspired, and was in turn inspired by, practices of visual and literary representation.'

32. See Faulkner (2008), 164-66 for identification of epiphanic motifs in this scene.

33. With this new approach, I expand upon Platt's evocative comment on the passage of the Sacred Tales at 2.32: 'This struggle to meet the god with all the senses, to translate a dematerialised form of oneiric theōria into conscious embodied experience...is arguably a driving force within the text' (Platt [2011], 263). On ST 2.32, see p.220 below. 
öv $\alpha \rho, \dot{\alpha} \lambda \lambda$ ’

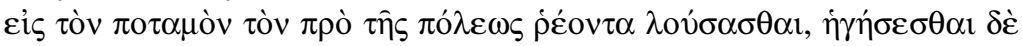

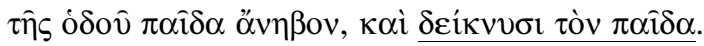

\begin{abstract}
When we arrived at Smyrna, he appeared to me in some such form. $\mathrm{He}$ was at the same time Asclepius, and Apollo, both the Clarian and he who is called the Callitecnus in Pergamum and whose is the first of the three temples. Standing before my bed in this form, when he had extended his fingers and calculated the time, he said: 'You have ten years from me and three from Sarapis', and at the same time the three and the ten appeared by the position of the fingers as seventeen. He said that this was not a dream, but a waking state, and that I would also know it. And at the same time he commanded that I go down to the river, which flows before the city, and bathe. He said that a young boy would lead the way. And he pointed out the boy.
\end{abstract}

In this passage, I have underlined features of kinesic style. Aristides' perception of Asclepius develops through his interaction with the god's two gestures (counting with the fingers and later pointing out the boy) in a precise spatial location (in front of the narrator's bed). Moreover, the double interpretation of the number conveyed by Asclepius' fingers stresses the need for Aristides to pay close attention to the god's gestures. ${ }^{34}$ Finally, as a result of this interaction, Aristides' perception is directed to a new spatial location, the river. On the other hand, Aristides does not tell us much about his visual impression of Asclepius; he compares the god with two statues of Apollo which have not survived to our time but which, given their provenance from Pergamum and the nearby Clarus, might have been known to readers of the $S T .^{35}$ Moreover, the blurring between Asclepius and his father Apollo seems to undermine the importance of reconstructing a specific portrait of the former god. Finally, not only the god but also every other given subject, such as the river and the city, lacks a detailed presentation.

34. This double interpretation was easy to understand for ancient readers: see Behr (1968), 71, whose explanation is thus summarised by Nicosia (1984), 227: 'Nel computo digitale, le unità venivano indicate con le dite di una mano, le cinquine con quella dell'altra. Ne consegue che lo stesso gesto ( 2 dita di una mano +3 dell'altra) può indicare sia $13(2 \times 5+3)$ che $17(3 \times 5+2)$.'

35. The statue of Apollo at Pergamum has not been reconstructed. As argued by Nicosia (1984), 227, 'il culto di Apollo nell' Asclepieo è attestato da alcuni iscrizioni..., ma le tracce del suo tempio non sono identificabili con certezza.' However, the statue of Apollo Clarius was likely to have become a common iconographical type since the prehellenistic era (4th century BCE), as shown by the appearance of this motif on Hellenistic coins: see LIMC II (1984), Apollon, no. 299, with the following description: 'A. steht in langem Chiton nach r., die gesenkte Linke auf die Lyra gelegt, in der vorgestreckten Rechten einen Zweig mit Wollbinden haltend. Langes Haar, unter einem Lorbeerkranz am Nacken in Locken auslaufend. Die Darstellung wird als Wiedergabe einer frühhellenistichen Statue des A. Klarios von Kolophon betrachtet.' 
Kinesic style also characterises Aristides' narrative of the god's second epiphany in the $S T$ :

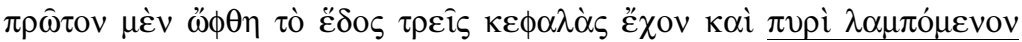

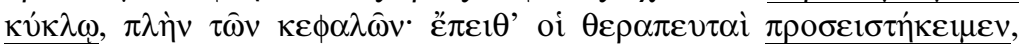

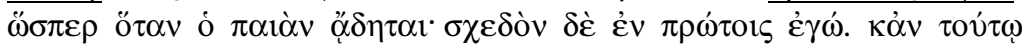

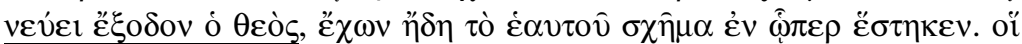

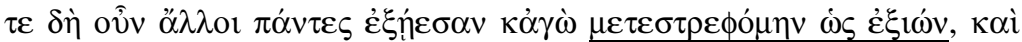

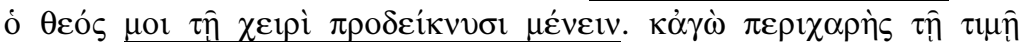

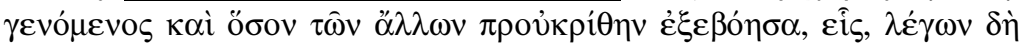

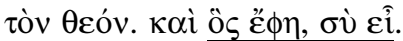

First the cult statue appeared to have three heads and to shine about with fire, except for the heads. Next we worshippers stood by it, just as when the paean is sung; I was almost among the first. At this point, the god, in the posture in which he is represented in his statues, signalled our departure. All the others were going out, and I was turning to go out, and the god, with his hand, indicated for me to stay. And I was delighted by the honour and the extent to which I was preferred to others, and I shouted out: 'The One', meaning the god. But he said, 'It is you'.

In this passage, Aristides' perception develops by interacting with Asclepius' gestures (one with the head and the other with the hand) in a given spatial location (a temple): we see here more features of kinesic style. Both gestures are marked in the text, the first one being the god's typical action in Greek literature since Homer, ${ }^{36}$ and the second one indicating Asclepius' preference for Aristides. Moreover, the god's spatial reference is also marked as Aristides portrays himself standing by the god's statue as in a paean. By taking this position, Aristides both performs a religious duty and puts himself in the best condition for perceiving the god. Finally, the key role of interaction is emphasised by the narrator's attempt to follow the other believers departing from the god, since here Aristides' attention is drawn not only to the god but also to his fellows. On the other hand, as in the previous passage, Aristides pays scant attention to his visual impression of the god: Asclepius takes the form of a three-headed statue - one that is difficult to connect with material evidence-and the fire shining around it seems to hide the god's details.

As a result, these two epiphanies display a marked use of kinesic style, through which Aristides' perception of Asclepius is presented as enactive. This assessment is original, because it does not conform to the purely visual approach to epiphany, and its effect on the readers will be discussed in section 2 below.

36. See Hom. Il. 1.524-30, the famous scene in which Zeus nods assent and Olympus trembles. 


\subsection{Aristides' Emotional and Multisensorial Perception of Asclepius}

Aristides' account of the epiphanies of Asclepius is enriched by another passage in which the narrator describes his overall reaction to the multiple appearances of the god. The language of this passage is richer than that of the epiphanies commented upon above, as it combines kinesic and cognitive style:

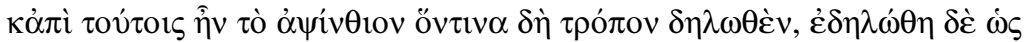

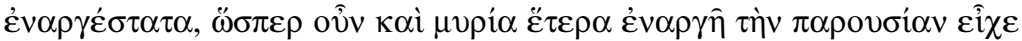

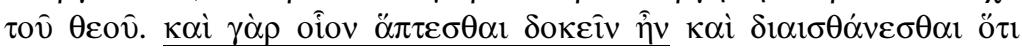

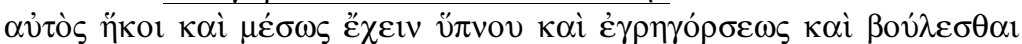

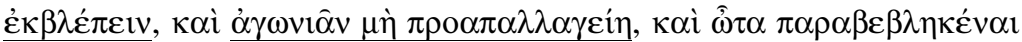

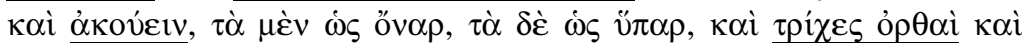

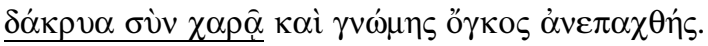

And after this there was the way in which the wormwood was revealed, and revealed in the clearest way possible, just as countless other things also clearly contained the presence of the god. For there was a seeming, as it were, to touch him and to perceive that he himself had come, and to be between sleep and waking, and to wish to look at him, and to be in anguish that he might depart too soon, and to strain the ears and to hear some things as in a dream, some as in a waking state. Hair stood straight, and there were tears with joy, and the pride of one's heart was without offence.

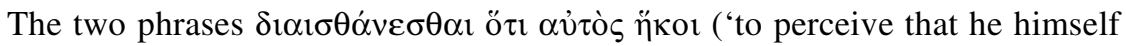

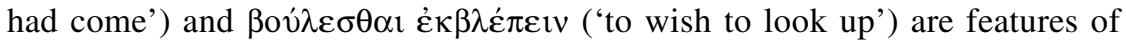
kinesic style that describe Aristides' interaction with Asclepius and confirm the enactive nature of his perception of the god. Moreover, this passage also contains elements of cognitive style: the narrator's multisensorial reactions including sight, touch and hearing; his emotions, represented by the anguish about the god's departure and the joy experienced because of his presence; and finally, bodily expressions, like his hair standing straight up and tears. As a result, here the involvement of the narrator's body assumes a greater dimension than in his epiphanic dreams of Asclepius: this passage both confirms the enactive nature of Aristides' perception of the divine and presents it more broadly as an embodied one.

\subsection{Aristides' Epiphanic Bath as the Apex of his Embodied Perception of Asclepius}

In books 2-6 of the $S T$, under Asclepius' will the narrator undertakes a series of regenerating baths, the first of which is presented by Aristides as 
an $\dot{\pi} \pi \phi \alpha ́ v \varepsilon \imath \alpha,{ }^{37}$ a term which closely links this passage to his dreams of Asclepius. More than in those epiphanies, however, here Aristides' embodied perception of the god gains a special strength:

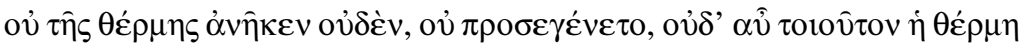

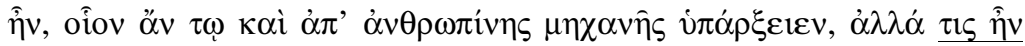

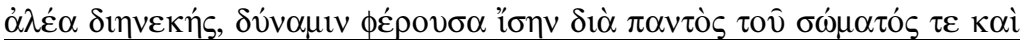

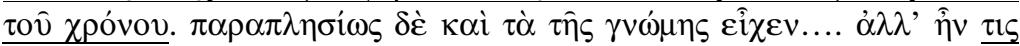

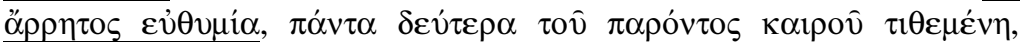

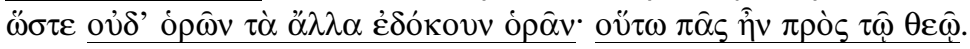

(ST 2.22-23)

None of the warmth abated, none was added, nor again was the warmth such as one would have from a human contrivance, but it was a certain continuous body heat, producing the same effect throughout the whole of my body and during the whole time. My mental state was also nearly the same.... But there was a certain inexpressible state of well-being, which regarded everything as less than the present moment, so that even while I was seeing other things, I seemed not to see them; to such an extent was I wholly in the presence of the god.

(my tr.)

Since throughout the ST Aristides' body is constantly subject to degeneration, the

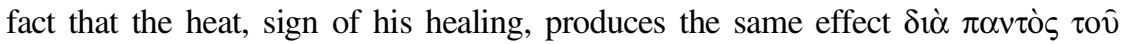

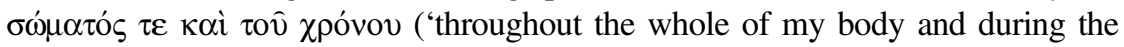
whole time') implies his achievement of an exceptional and supernatural status,

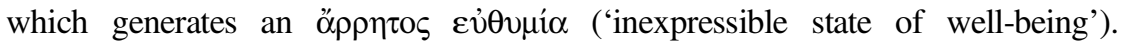
Through this heat, then, as argued by Downie, ${ }^{38}$ Aristides makes his own body 'a vehicle of divine presence'. This divinisation constitutes the apex of his embodied perception of Asclepius, and the last phrase of the above passage confirms this, by arguing that Aristides is now 'wholly- $\pi \hat{\alpha} \varsigma$ - in the presence of the god'.

\section{The Reader's Embodied and Enactive Experience of the Divine}

In this section, I will explore how Aristides' perception of the divine affects the reader's, again with the help of Platt's analysis.

The Greek epiphanic discourse is based on the 'cognitive dilemma' of whether 'a real experience of the divine' 39 can be achieved by readers of literature and

37. See $S T 2.20$.

38. Downie (2013), 108.

39. I draw this phrase from Platt (2011), 4, and I will use it throughout this section to designate the event of encountering the god through the text. 
thus through the mediation of human representation, ${ }^{40}$ and the most common answer is negative, as through language 'the immediacy of the divine eidos is lost' ${ }^{41}$ Still according to Platt's view, this negative answer is reinforced from the Hellenistic time onwards, when, starting with Hellenistic poetry, the link between epiphanies and ekphraseis discussed in section 1.1 of this article is closely established. ${ }^{42}$ In the most common scholarly view, in fact, ekphraseis both strive to make present the described object and, at the same time, through their technical language divert the readers' attention to their own artifice, thus undermining their experience of the conveyed object. ${ }^{43}$

In the $S T$ the 'cognitive dilemma' mentioned above specifically concerns Aristides' perception of the divine: can the narrator, with his enactive and embodied account focused on Asclepius, lead readers to gain an experience of the divine through an embodied simulation? On many occasions Aristides offers a negative answer confirming the truth of Platt's argument, since he shows his own awareness of the limits that literary mediation imposes on the account of his perception of Asclepius. A first type of narratorial comment stresses the impossibility of narrating all the deeds of the god:

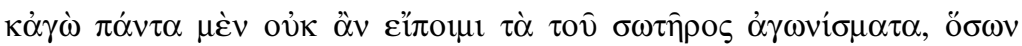

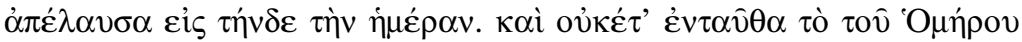
$\pi \rho \circ \sigma \theta \dot{\eta} \sigma \omega$,

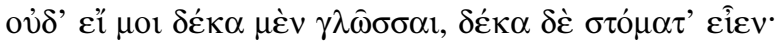

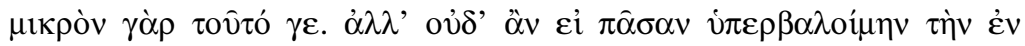

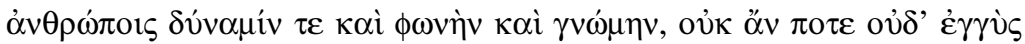

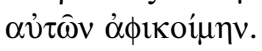

$(S T$ 1.1)

And I myself would not tell all the achievements of the Saviour, which I have enjoyed to this day. Nor at this point shall I add that Homeric phrase, 'not if I had ten tongues, ten mouths'. For this were too little. Not even if I should surpass all human strength, speech and wisdom, could I ever come close to them.

(my tr.)

Here the gap between Aristides' narration and his perception of the god is expressed by stressing the great number and special nature of Asclepius' actions. Moreover, as noted by Whitmarsh, Aristides' subtle exploitation of the

40. This dilemma is the key issue of Platt (2011).

41. Platt (2011), 59.

42. See Platt (2011), 173, arguing that in Hellenistic poetry 'the enargeia that characterised epiphanic encounter in the Homeric corpus...is reformulated as the enargeia of ekphrasis'.

43. See Platt (2011), 174, relying upon Bartsch and Elsner (2007), vi. 
motif of the ten tongues drawn from the Iliadic Catalogue of Ships ${ }^{44}$ directs the readers' attention to his own voice and thus points out the artificiality of the narration. In this way, the distance between the text and Aristides' perception of the god is enlarged, and readers are made unable to get a 'real experience' of the divine by reading the $S T$. The same effect is produced at the beginning of Book 2, when Aristides stresses the ineffability of his divine subject matter:

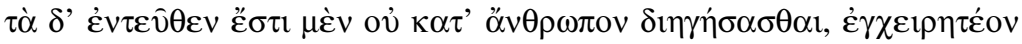

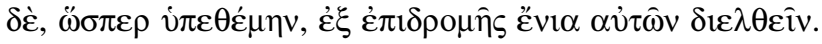

What came next it is not possible to narrate for a man. Still I must try, as I have proposed to do, to recount some of these things in a cursory way.

(my tr.)

Narratorial comments of this kind, which stress both the limit and the mediation of Aristides' narratorial activity, ${ }^{45}$ suggest that readers of the $S T$ were unlikely to have a 'real experience' of Asclepius and encounter the god through the text.

At the same time, Platt adds a further useful point to this discussion, when she argues that writers of epiphanies often find devices to overcome the limit of literary mediation and invite the reader to come close to and simulate the perception of the divine described in the text. ${ }^{46}$ Among these devices a popular one is the mimetic reenactment of divine ritual which is a distinctive feature of Callimachus' Hymn to Athena: in this text, Callimachus gives a special vividness to Athena's epiphany by making the goddess appear in a ritual and inviting the reader to participate in it. ${ }^{47}$

I now argue that in the $S T$ Aristides adopts a specific kind of narratorial comment as a device inviting readers to get close to a 'real experience' of the divine $^{48}$ and feel that they are in the presence of the god. ${ }^{49}$ To the passage and comment mentioned just above, Aristides adds a few interesting words:

44. See Il. 2.489 and Whitmarsh (2004a), 443.

45. For more narratorial comments stressing the mediation, see $S T 2.24,37,45,60,71,73 ; 4.63$, 68, 70. For one focused on the limit, see ST 2.33.

46. I draw the notion of simulation of experience from the cognitive studies scholar Gallese (2011).

47. See Platt (2011), 175-80.

48. I rely upon Kukkonen's embodied model of the reader-one which 'takes into account the readers' embodied responses' (Kukkonen [2014], 367).

49. With this notion of 'being in the presence of' when reading a text I refer to what scholars normally define as immersion (Ryan 2001), mimesis (Halliwell 2002), experience (Grethlein 2013) or cognitive realism (Troscianko 2014). In this article I mostly use the term experience, in agreement with Platt's exploitation of this term with respect to epiphanies (see her notion of 'real experience' of the divine discussed above). 


\section{ALDO TAGLIABUE}

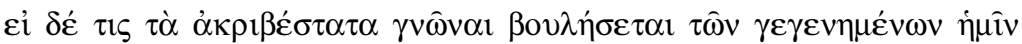

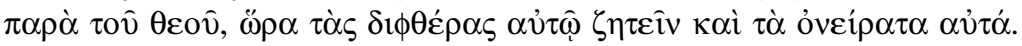

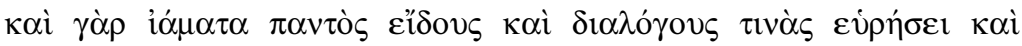

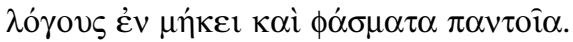

But if someone will wish to know very precisely what has befallen us from the god, it is time for him to seek out the parchment books and the dreams themselves. For he will find cures of all kinds and some discourses and full scale orations and all kinds of visions.

Here Aristides makes a point about the inaccuracy of his narration by drawing a distinction between his brief text and some detailed written records of his dreams. ${ }^{50}$ As a result of this distinction, the narration of the $S T$ takes a peculiar

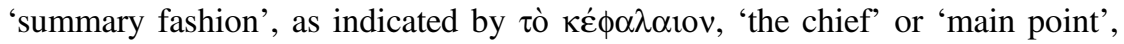
a programmatic term which either in the singular or in the plural occurs ten times in the text starting from the prologue to Book $2:^{51}$

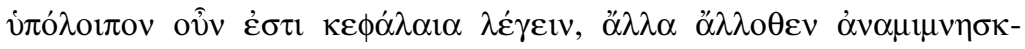

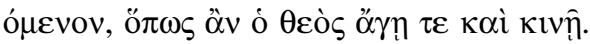

The only thing left is to speak in summary fashion, as I remember different things from different sources, howsoever the god will lead and stimulate me.

Strikingly, this acknowledgment of the inaccuracy of his narration, when applied to Aristides' epiphanic dreams of Asclepius, assumes a different colour, as it paradoxically invites readers to get close to gain a 'real experience' of the divine rather than distancing them from it. At the end of his first enactive dream of Asclepius, Aristides thus writes:

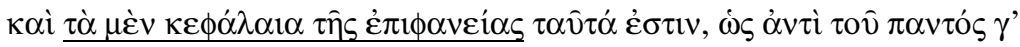

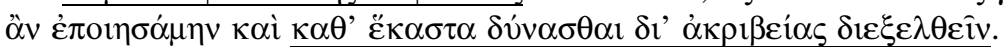

(ST. 2.18)

These are the main points of the divine manifestation, and I would value above everything else to be able to recount exactly each particular of it.

(my tr.)

50. The same distinction is drawn at 2.3. Many scholars have commented upon it from a different angle, associating the mention of written records with either the diary narrative of Book 1 (see Quet [1993], 220) or with the chronological record of events which Aristides decided to interrupt from Book 2 onwards (see Pearcy [1988], 381f., and Whitmarsh [2004a], 444).

51. Cf. ST 2.18, 2.29, 3.5, 3.13, 3.48, 4.77, 4.80, 4.98 and 5.23. 
At a first glance, this comment stresses the incompleteness of the dream description and seems to enlarge the distance between the given text and Asclepius' appearance. However, on closer examination, in the context of the enactive dream both the references to 'the main points' and to the dream's lack of accuracy have a more profound meaning. To begin with, with $\tau \grave{\alpha} \mu \dot{\varepsilon} v$ $\kappa \varepsilon \phi \alpha \dot{\lambda} \alpha 1 \alpha$, 'the main points', the narrator indicates Asclepius' locations, gestures and actions; in other words, the enactive features of his dream. By introducing this term, then, Aristides subtly inspires his readers to get close to gain a 'real' and enactive experience of Asclepius. Moreover, the following reference to inaccuracy may subtly hint at Aristides' omission of physical details about Asclepius: in other words, with this narratorial comment Aristides seems to invite readers to acknowledge his preference for an enactive rather than for a purely visual perception of the god.

The effect of this invitation can be further discussed with the help of two cognitive studies scholars, Kuzmičová and Troscianko, who have recently argued that enactive accounts might have a stronger, more vivid quality than purely visual ones. ${ }^{52}$ More precisely, Kuzmičová argues that enactive accounts lead readers to have an impression of being in the presence of the given subject. ${ }^{53}$ Moreover, Troscianko identifies two textual elements that especially promote this effect, namely spatial references and a paucity of details, and uses this second feature to argue against the most standard view, according to which the impression of presence through literature (and thus experience) can only be achieved if the given passages are full of details. ${ }^{54}$ In Troscianko's view, conversely, gaps perform a positive function, as by stimulating the reader's imaginative power they have a special, vivid effect. ${ }^{55}$ This framework invites us to a further assessment of Aristides' enactive dreams of Asclepius, in which the narrator, as we saw in section 1.1, perceives the god by interacting with him in precise spatial locations and, at the same time, leaves gaps about the god's appearance. I would now argue that these passages not only lead readers to simulate an experience of the divine, but that this simulation is possibly more effective than one promoted by purely visual descriptions of the same god.

Finally, in the $S T$ an experiential effect is also produced by another type of narratorial comment, which presents Aristides' embodied perception of the divine as exclusive. In Aristides' baths the narrator often stresses the hardship of the

52. Both scholars rely upon Noë’s sensorimotor enactivism: see Noë (2004), 12: 'The basic claim of the enactive approach is that the perceiver's ability to perceive is constituted (in part) by sensorimotor knowledge (i.e., by practical grasp of the way sensory stimulation varies as the perceiver moves).'

53. See Kuzmičová (2012), 25, for presence as the impression 'of having physically entered a tangible environment'. See also Grethlein and Huitink (forthcoming) for further discussion of enactive accounts, with additional bibliographical references.

54. See e.g. Troscianko (2014), 41-43, and section 1.1 of this article.

55. See Troscianko (2014), 112, commenting upon 'the imagination's ease with indeterminacy and unfilled gaps'. 
weather conditions ${ }^{56}$ to the point of 'staging his physical exploits as agonistic competitions against fellow worshippers' 57 and presenting himself as the only one who undergoes divinisation. Since, as argued in the introduction, the ancient readers of the $S T$ were connected with Asclepius' cult, it is likely that they were engaged in this competition launched by Aristides and tried to emulate him. As a result of these attempts, they could get close to achieving a 'real' and embodied 'experience' of Asclepius by reading the ST.

A similar interpretation applies to the conclusion of Aristides' remark about his multisensorial perception of the divine:

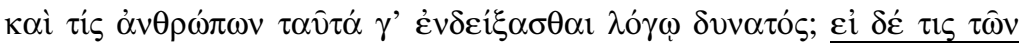

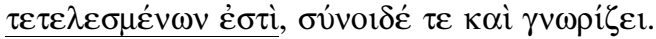

And what man could describe these things in words? If any man has been initiated, he knows and understands.

This passage on the one hand confirms Aristides' inability to convey his perception of the divine in words, and on the other hand, presents it as accessible only to a group of initiates. Aristides probably considers himself a member of this group, since throughout the $S T$ he often portrays himself as a special devotee of Asclepius, and the conditional clause 'if any man has been initiated' establishes a potential competition between the narrator and his readers. As a result of it, some of the latter might be inspired to become initiated too and simulate with their bodies the experience of the divine described by Aristides. ${ }^{58}$

In conclusion, through a variety of narratorial comments Aristides faces the difficulty of conveying the divine through literature and at the same time exploits certain devices to invite readers to gain a 'real', embodied and enactive experience of Asclepius.

\section{Conclusion}

This article advances a new reading of epiphanic dreams of Asclepius by taking them as accounts of Aristides' embodied and enactive perception of the

56. See Downie (2013), 110: 'In every case...his physical condition and the harsh weather conditions in which he undertook the baths made the miracle of divine protection fully apparent.'

57. Downie (2013), 103; see ST 2.35, 2.47, 2.76; 2.79. See also Downie ibid.: 'In HL II and III, Aristides boasts of going barefoot in the winter, practising open-air incubation, going without an undershirt (II.80), and racing on horseback (III.5).' For other passages in which Aristides boasts about his own qualities, see $S T$ 2.12, 3.2, 3.43 (with an overt reference to his own popularity) and 4.4 (with the mention of his own consecration to and possession by Asclepius).

58. Here I am very close to Petsalis-Diomidis's interpretation of this passage, for which see Petsalis-Diomidis (2006), 200: 'The conclusion of the passage clearly aims to elicit a personal response or memory in the reader.' 
god-one which readers of the Sacred Tales are invited to simulate. The identification of cognitive and kinesic style in the text and discussion of narratorial comments by Aristides are the key points of this interpretation.

This reading offers new evidence about the relevance of both religion (through Aristides' perception of the divine) and rhetoric (through narratorial comments) for the understanding of the ST. Moreover, it sheds new light on the role of epiphanies in ancient literature, by suggesting that in them the human body-and more precisely embodied and enactive perception-might play a more important role than is usually thought, an interpretation which would challenge the visual paradigm traditionally attributed to this important device of ancient literature.

In the limited space of this article, the potential of this suggestion can be investigated through analysis of an extract of the perhaps most famous of Homer's epiphanies, the appearance of Athena in Book 1 of the Iliad:

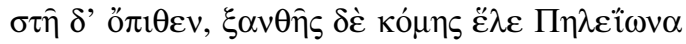

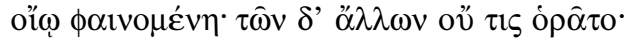

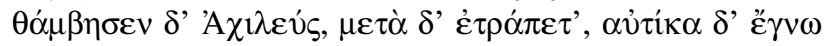

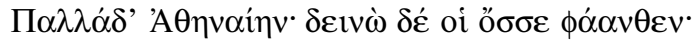

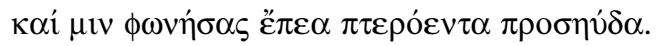

The goddess stood behind, and seized Peleus' son by his fair hair, appearing to him only, for no man of the others saw her.

Achilles in amazement turned about, and straightaway knew Pallas Athena, and the eyes shone terribly. And addressing her he uttered winged words.

(tr. Lattimore, with some adaptations)

Some scholars apply to this passage a purely visual kind of interpretation, as we see with Erwin who argues that 'Athena's general lack of concealment or disguise highlights the significance of Achilles' visual recognition'. ${ }^{9}$ Such an analysis, however, misses an important element noted by Pucci, namely that Athena's 'physical presence is not sketched or represented in any way' 60 and that the goddess 'acquires attributes and precise powers through her abrupt appearance and tremendous, authoritative gesturality'. ${ }^{61}$ This priority given to gestures over physical description is the same that we have identified in Aristides' epiphanies. Moreover, scholars have noted the originality of Athena's positioning herself behind Achilles - one that in the Iliad usually makes the god involved

59. Erwin (2013), 47f.

60. Pucci (1998), 69. For the sake of space, I do not discuss here the controversial mention of 'terrible eyes shining', which is impossible to assign definitively to Achilles or Athena. On this issue, see Turkeltaub (2005), whose article gives also a rich bibliography on this epiphany.

61. Pucci (1998), 76. 
invisible ${ }^{62}$ - and the consequent interpretive difficulty, as 'while the text asserts that Athena is visible only to Achilles, in reality he cannot yet see her' ${ }^{63}$ I find myself struck that Achilles' wonder at line 199, a reaction typical of ancient epiphanies, ${ }^{64}$ is here specifically directed to a spatial location-Athena's position behind Achilles: Achilles' subsequent turning describes his enactive perception of the goddess. Moreover, as we saw with Aristides' logic of competition, the fact that the goddess is said to be inaccessible to others is a device that might have encouraged the ancient hearer or reader of the Iliad to simulate an experience of Athena.

As a result of this analysis, I would conclude that with their enactive and embodied nature Aristides' epiphanies of Asclepius point to an important aspect of the ancient method of configuring epiphanies, one that needs more scholarly attention and might change our way of interpreting the ancient configuration of the divine through literature. ${ }^{65}$

Universität Heidelberg

aldo.tagliabue@skph.uni-heidelberg.de

\section{Bibliography}

Bartsch, S., and J. Elsner (2007), 'Introduction: Eight Ways of Looking at an Ekphrasis', CPh 102, i-vi.

Baumgart, H. (1874), Aelius Aristides als Repräsentant der sophistischen Rhetorik des zweiten Jahrhunderts der Kaiserzeit (Leipzig).

Behr, C.A. (1968), Aelius Aristides and the Sacred Tales (Amsterdam).

(tr.) (1981), P. Aelius Aristides, Complete Works Vol. 2: Orations XVII-LIII (Leiden).

Bolens, G. (2012), The Style of Gestures: Embodiment in Cognition and Literary Narrative (Baltimore MD).

Butler, S., and A. Purves (eds.) (2013), Synaesthesia and the Ancient Senses (Durham).

Damasio, A. (1999), The Feeling of What Happens: Body and Emotion in the Making of Consciousness (London).

62. See Pucci (1998), 72, on this epic convention, with discussion of some passages (e.g. Il. 15.694f.).

63. Pucci (1998), 73.

64. See Richardson (1974), 208, and Faulkner (2008), 164.

65. I would like to thank the anonymous referees at Ramus and the editor, Helen Morales, for their very helpful criticism. I am also grateful to Jonas Grethlein, Karen Kukkonen, Angela Harkins, Lawrence Kim, Marco Caracciolo and Benjamin Allgaier for commenting on earlier drafts of this article. I also thank the audiences of the workshop 'Embodiment and Literature' (Schöntal, March 2015), of the conference 'Triangulationship' (Cambridge, July 2015), of the 'Religious Experience in Antiquity' Unit (Atlanta, SBL Annual Meeting, November 2015) and the Department of Classics at Chapel Hill (November 2015) for their useful feedback. Special thanks to John Penwill, Associate Editor of Ramus, for his editorial acumen and help in preparing my typescript for the press. The research for this article was made possible by the European Research Council under the European Union's Seventh Framework Programme (FP/2007-2013) / ERC Grant Agreement n. 312321 (AncNar). 
de Jong, I.J.F., R. Nünlist and A. Bowie (eds.) (2004), Narrators, Narratees, and Narratives in Ancient Greek Literature (Leiden/Boston).

Dindorf, W. (1964), Aristides, vol. 1 (Hildesheim) [orig. publ. 1829].

Downie, J. (2013), At the Limits of Art: A Literary Study of Aelius Aristides' Hieroi Logoi (Oxford).

Erwin, P. (2013), 'Epiphany Reconsidered: A Parallel Reading of Acts 9:1-9 and Iliad 1.188-224a', in S. Alkier and A. Weissenrieder (eds.), Miracles Revisited: New Testament Miracle Stories and their Concepts of Reality (Berlin/Boston), 33-54.

Faulkner, A. (2008), The Homeric Hymn to Aphrodite: Introduction, Text, and Commentary (Oxford/New York).

Gallagher, S. (2005), How the Body Shapes the Mind (Cambridge).

Gallese, V. (2011), 'Embodied Simulation Theory: Imagination and Narrative', Neuropsychoanalysis 13, 196-200.

Goldhill, S. (2001), 'The Erotic Eye: Visual Stimulation and Cultural Conflict', in Being Greek under Rome: Cultural Identity, the Second Sophistic and the Development of Empire (Cambridge), 154-94.

Gordon, R. (1979), 'The Real and the Imaginary: Production and Religion in the GrecoRoman World', Art History 2, 5-34.

Grethlein, J. (2013), Experience and Teleology in Ancient Historiography: Futures Past from Herodotus to Augustine (Cambridge).

and L. Huitink (forthcoming), 'Homer's Vividness: An Enactive Approach', JHS.

Halliwell, S. (2002), The Aesthetics of Mimesis: Ancient Texts and Modern Problems (Princeton).

Harkins, A.K. (2012a), Reading with an 'I' to the Heavens: Looking at the Qumran Hodayot through the Lens of Visionary Traditions (Berlin). - (2012b), 'Religious Experience through the Lens of Critical Spatiality: A Look at Embodiment Language in Prayers and Hymns', in C. Shantz and R. Werline (eds.), Experientia, Vol. 2: Linking Text and Experience (Atlanta GA), 223-42.

Harvey, S.A. (2006), Scenting Salvation: Ancient Christianity and the Olfactory Imagination (Berkeley).

Herman, D. (2012), 'Narrative Theory after the Second Cognitive Revolution', in L. Zunshine (ed.), Introduction to Cognitive Cultural Studies (Baltimore MD), 155-75.

Holmes, B. (2008), 'Aelius Aristides' Illegible Body', in W.V. Harris and B. Holmes (eds.), Aelius Aristides between Greece, Rome, and the Gods (Leiden/Boston), 81-114.

Israelowich, I. (2012), Society, Medicine and Religion in the Sacred Tales of Aelius Aristides (Leiden/Boston).

Kukkonen, K. (2014), 'Presence and Prediction: The Embodied Reader's Cascades of Cognition', Style 48, 367-84.

and M. Caracciolo (2014), 'What is the "Second Generation”?', Style 48, 261-74.

Kuzmičová, A. (2012), 'Presence in the Reading of Literary Narrative: A Case for Motor Enactment', Semiotica 189, 23-48.

Morales, H. (2004), Vision and Narrative in Achilles Tatius' Leucippe and Clitophon (Cambridge).

Nicosia, S. (tr.) (1984), Elio Aristide, Discorsi sacri (Milan).

Noë, A. (2004), Action in Perception (Cambridge MA).

Pearcy, L.T. (1988), 'Theme, Dream and Narrative: Reading the Sacred Tales of Aelius Aristides', TAPhA 118, 377-91.

Petsalis-Diomidis, A. (2006), 'Sacred Writing, Sacred Reading: The Function of Aelius Aristides' Self-Presentation as Author in the Sacred Tales', in J. Mossman and B. McGing (eds.), The Limits of Ancient Biography (Swansea), 193-211.

(2010), Truly Beyond Wonders: Aelius Aristides and the Cult of Asklepios (Oxford). 


\section{ALDO TAGLIABUE}

Platt, V.J. (2011), Facing the Gods: Epiphany and Representation in Graeco-Roman Art, Literature and Religion (Cambridge).

Pucci, P. (1998), The Songs of the Sirens: Essays on Homer (Lanham MD).

Quet, M.H. (1993), 'Parler de soi pour louer son dieu: le cas d'Aelius Aristide', in M.-F. Baslez, P. Hoffmann and L. Pernot (eds.), L'invention de l'autobiographie d'Hésiode à Saint Augustin (Paris), 211-21.

Richardson, N. (1974), The Homeric Hymn to Demeter (Oxford).

Rutherford, I. (2013), State Pilgrims and Sacred Observers in Ancient Greece: A Study of Theōria and Theōroi (Cambridge/New York).

Ryan, M.L. (2001), Narrative as Virtual Reality: Immersion and Interactivity in Literature and Electronic Media (Baltimore MD).

Squire, M. (2009), Image and Text in Graeco-Roman Antiquity (Cambridge/New York).

Troscianko, E. (2014), Kafka's Cognitive Realism (London).

Turkeltaub, D.W. (2005), 'The Syntax and Semantics of Homeric Glowing Eyes: Iliad 1.200', AJPh 126, 157-86.

Webb, R. (2009), Ekphrasis, Imagination and Persuasion in Ancient Rhetorical Theory and Practice (Farnham).

Whitmarsh, T. (2004a), 'Aelius Aristides', in de Jong et al. (above), 441-47. (2004b), 'Philostratus', in de Jong et al. (above), 423-39. 